\title{
Imagens de violência de gênero em telenovelas brasileiras
}

\author{
Lorena Rúbia Pereira Caminhas
}

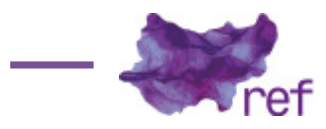

Resumo: O presente artigo investiga o modo como é retratada a violência perpetrada contra as vilãs de telenovelas brasileiras, por seus pais, maridos e amantes. Questiona se as cenas nas quais essas mulheres são agredidas estão inseridas em um contexto no qual tal violência é declarada e questionada, ou se elas aparecem destituídas de qualquer indagação sobre o fato de se representar um homem batendo em uma mulher. Foram selecionadas nove novelas para análise, exibidas entre os anos 2000 a 2017, sendo todas "novelas das oito" apresentadas no horário nobre (21 horas). Ao final do percurso, buscou-se evidenciar um regime de representação que nega a violência de gênero inerente a essas imagens e suas possíveis consequências.

Palavras-chave: regimes de representação; violência de gênero; telenovelas

Images of Gender Violence in Brazillian Soap Operas

Abstract: This article investigates the portrayal of the violence perpetrated against the villains of Brazilian soap operas by their parents, husbands and lovers. The main question is about whether the scenes in which these women are assaulted are inserted in a context in which such violence is stated and questioned, or if they appear devoid of any inquiry about the depiction of a man beating a woman. Nine soap operas were selected for analysis: all were exhibited between the years of 2000 to 2017 and were presented in prime time (21 o'clock). At the end of the course, the investigation demonstrates a regime of representation that denies the gender violence inherent in these images and their possible consequences.

Keywords: Regimes of representation; Gender violence; Soap operas.

\section{Introdução}

Em 2000, íris é puxada violentamente pelo braço e agredida por seu par romântico, Pedro. Em 2003 é a vez de Dóris ser açoitada pelo pai em diversas ocasiões. Em 2005, May é empurrada e ameaçada pelo seu ex-namorado. Em 2006, Marta é esganada pelo marido enquanto está acamada. Em 2012, Carmem Lúcia é espancada pelo amante e leva um tapa na cara do marido. Em 2013, Lívia é enforcada por seu parceiro erótico. No ano de 2014, Cora é enforcada duas vezes pelo homem por quem está apaixonada. Em 2015, Atena é presa com uma coleira e mantida em cativeiro pelo seu ex-marido. Em 2017, Magnólia apanha de seu ex-marido e ganha um soco de seu amante.

As cenas de violência acima descritas são ocorrências comuns no cotidiano brasileiro, no qual uma em cada cinco mulheres já sofreram algum tipo de agressão perpetrada por conhecidos e desconhecidos. Ocorrem cinco espancamentos de mulheres a cada dois minutos, um estupro a cada 11 minutos, um feminicídio a cada 90 minutos, 179 relatos de agressão por dia'. Essas modalidades de violência contra a mulher partem, sobretudo, dos homens mais próximos: em

\footnotetext{
1 Dados retirados do dossiê "Violência contra as mulheres", produzido pelo Instituto Patrícia Galvão, acessado em:
} http://www.agenciapatriciagalvao.org.br/dossie/sobre-as-violencias-contra-a-mulher/ 


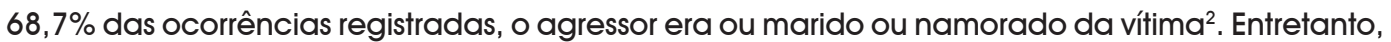
tais cenas não foram retiradas de relatos jornalísticos, mas dos últimos 17 anos de exibição de telenovelas brasileiras. Trata-se de vilãs apanhando de pais, amantes e maridos.

Diante do contexto brasileiro no qual proliferam, em rede nacional, imagens ficcionais de mulheres apanhando de homens e multiplicam os números de violência e assassinatos de mulheres no plano factual, o presente texto questiona o regime de representação que rege as cenas de agressão contra as vilãs, buscando compreender como ele as caracteriza e as qualifica. Trata-se de expor a brutalidade da situação em um quadro de reflexão sobre o problema? Ou tais cenas são tratadas como algo usual, livre de questionamentos? Ademais, propõe uma reflexão acerca das dimensões de gênero impregnadas na ocasião das agressões e humilhações, interrogando se existe uma naturalização da violência de gênero na teledramaturgia brasileira. Para tanto, foram analisadas, ao longo deste texto, as cenas de violência de personagens masculinos contra as vilãs de nove telenovelas ${ }^{3}$ exibidas entre os anos 2000 e 2017 pela Rede Globo de Televisão, sendo todas "novelas das oito", apresentadas em horário nobre brasileiro (21 horas).

\section{Corpus e percurso analítico}

No contexto brasileiro, a Rede Globo de Televisão é a principal produtora de telenovelas, proporcionando a exibição de cinco narrativas ficcionais de segunda a sábado em horários diversificados: a) durante o período da tarde são apresentadas duas novelas, uma reprise e outra voltada ao público adolescente (denominada Malhação); b) na faixa de horário noturna são transmitidas outras três, distribuídas entre os telejornais (18h, 19h e 21h). Apesar da expressiva quantidade de enredos elaborados e televisionados, a "novela das oito" (nome atribuído à trama exibida às 21 horas) é a principal e nela são discutidos temas considerados relevantes no contexto nacional, com forte estímulo ao debate público. Ela possui, inclusive, os maiores índices de audiência do segmento.

No decorrer dos 17 anos que englobam esta análise, foram apresentadas 27 telenovelas no horário nobre brasileiro, sendo 15 produções dos anos 2000 e outras 12 dos anos de 2010. Desse total, apenas em três novelas não apareceram vilãs centrais, mas sim vilões (homens assumindo o papel de malfeitores) ${ }^{4}$ e em uma delas a vilã era uma personagem mirim ${ }^{5}$. Nas demais narrativas, que não constam da amostra em investigação, as vilãs apanhavam de outras mulheres, geralmente as heroínas.

O corpus selecionado (nove novelas) corresponde a quatro anos e sete meses de exibição de narrativas ficcionais em horário nobre, totalizando 1.701 episódios e correspondendo a um terço da produção dos últimos 17 anos. Ele compõe todas as telenovelas apresentadas entre 2000 a 2017 , nas quais as vilãs apanharam de homens, principalmente seus amantes, maridos e pais. Para o estudo, foram elegidas as principais cenas de agressão, identificadas a partir dos resumos da semana publicados em versões eletrônicas de revistas especializadas em televisão. Ressaltase que as mulheres sofreram violência ao longo de toda a trama, perpetrada por homens e outras mulheres. Em geral, as cenas em relevo obtiveram alto índice de audiência e grande repercussão nos veículos de mídia.

A presente investigação compreende as imagens e narrativas televisivas como importantes fontes de análise qualitativa, na medida em que elas distribuem representações e disseminam significados a respeito do mundo social, atuando como formadores de opinião (Peter LOIZOS, 2002). A análise empreendida considerou os procedimentos elencado por Diana Rose (2002), selecionando cenas específicas nas quais foram observados os tipos de agressão física (bater, chutar, esganar, socar, empurrar, espancar) e morais (os tipos de humilhação promovidos e xingamentos vociferados) sofridos pelas mulheres, e também examinando o contexto no qual se insere a violência (a situação da vilã na trama e na cena específica) a partir de descrições desses momentos.

\section{Bater em vilã pode?}

Na primeira metade do ano 2000 está no ar a telenovela Laços de Família (Manoel CARLOS, 2000). Íris (Deborah Secco) é a meia-irmã da personagem principal Helena (Vera Fischer) que detesta a sobrinha Camila (Carolina Dieckmann). Durante a trama, a vilã se esforça para atrapalhar o romance de Camila com Edu (Reinaldo Gianechinni) por considerar um absurdo a sobrinha ter "roubado" o namorado da mãe. Íris é apaixonada por Pedro (José Meyer), e o persegue a todo o momento, sendo capaz de tudo para conquistá-lo. Durante a narrativa, íris é considerada uma

\footnotetext{
2 Os dados foram obtidos da Síntese dos Indicadores Sociais (SIS) divulgada pelo Instituto Brasileiro de Geografia e Estatística em 2010, e podem ser acessados em: http://biblioteca.ibge.gov.br/pt/biblioteca-catalogo?view=detalhes\&id $=245700$

${ }^{3}$ Laços de Família (2000), Mulheres Apaixonadas (2003), América (2005), Páginas da Vida (2006), Avenida Brasil (2012), Salve Jorge (2012/2013), Império (2014), A Regra do Jogo (2015) e A Lei do Amor (2016/2017).

${ }^{4}$ São elas: Duas caras (2007), Amor à vida (2013) e Velho Chico (2016).

${ }^{5}$ Telenovela Viver a vida (2009).
} 
mulher "oferecida" e "exibida", que se insinua para os homens. No vigésimo primeiro episódio da narrativa, apresentado no dia 21 de julho, vemos íris apanhar de seu par romântico: a vilã passa a morar no haras coordenado por Pedro e, na cena, está se arrumando para sair com Fábio (Max Fercondini). Pedro, enfurecido, ordena que ela tire a "fantasia", mas a garota não obedece. Pedro leva a moça até o chuveiro a força, coloca-a embaixo da água e afirma "Vai me agradecer, ia se oferecer, ia estragar sua vida. Agora bota uma camisola e vai dormir, não quero mais olhar na sua cara". Íris, em um surto de raiva, xinga Pedro, que puxa o cabelo da vilã, coloca-a deitada na cama e começa a bater em sua bunda. Enquanto bate, ele avisa: "Quer apanhar mais? Não aprendeu, não? Vai apanhar sim, agora. Foi isso que faltou na sua vida, uma boa palmada. Seu pai era muito velho, sem força. Agora você vai aprender por bem ou por mal, vai criar juízo". Os tapas e empurrões de Pedro funcionam como disciplinamento de Íris: somente após passar pela "mão firme" do homem é que ela muda sua atitude "oferecida" e "exibida". No fim da novela, eles se casam e Íris aparece grávida.

Em Mulheres Apaixonadas (Manoel CARLOS, 2003), a agressão de Carlão (Marcos Caruso) contra Dóris (Regiane Alves) tem a mesma função disciplinadora que o caso anterior, na medida em que o pai ensina a sua filha como agir de acordo com aquilo que se espera de uma boa filha e de uma mulher respeitável. Dóris mora com os pais e os avós em um apartamento de classe média, mas não gosta de seu estilo de vida. Ela maltrata seus avós constantemente, porque os culpa de piorarem sua situação dentro de casa. A vilã almeja conquistar uma vida de luxo e requinte fora da residência dos pais, e por isso sai com vários homens para conseguir presentes e vantagens. Cansado do desrespeito da filha, no quadragésimo primeiro capítulo (04 de abril), Carlão a tranca no quarto e bate nela com um cinto enquanto grita que ela precisa aprender a respeitar os outros e a se comportar como uma pessoa decente: "Você vai me ouvir Dóris, e vai aprender a respeitar os outros". Após várias discussões e agressões entre Carlão e Dóris, durante o desfecho da novela (apresentado em 10 de outubro), o pai opta por uma atitude mais drástica para "consertar" a filha definitivamente. Ele se direciona para o hotel no qual a vilã, sua filha, está com um amante, bate na porta do quarto, entra enfurecido e começa a xingá-la. Ele retira o cinto de suas calças e golpeia o corpo da garota, vociferando que agora ela vai aprender a se portar como uma "mulher decente". Após açoitar a filha, Carlão a leva para o hall do hotel, segura-a pelo pescoço e a expõe para todos os presentes. Dóris está com as roupas rasgadas, marcada da surra e mal se aguenta em pé. Carlão anuncia: "Esta é minha filha, e esse é o resultado de uma péssima educação".

As duas vilãs apresentadas até o momento apanharam por serem mulheres que destoaram dos padrões de conduta atribuídos ao gênero feminino, já que usaram roupas sensuais e provocantes, saíram com diversos homens, se ofereceram em troca de dinheiro ou vantagens, não se importaram com sua família (inclusive a desrespeitando em vários momentos). Pedro e Carlão assumiram, nas narrativas, a função de regular e disciplinar, ensinando às personagens como se portar e quais valores adotar. Nas outras cenas analisadas, os homens também assumem a função de corrigir o comportamento das mulheres (censurando as inadequadas), mas a partir de uma posição distinta do paternalismo presente nas figuras de Pedro e Carlão.

Na telenovela América. (Glória PEREZ, 2005), a vilã May (Camila Morgado) é namorada de Edward (Caco Ciocler). No decorrer da trama, Edward se apaixona pela heroína Marisol (Deborah Secco), e começa a se afastar de May que, durante a narrativa, é retratada como uma mulher obcecada e capaz de tudo para manter seu relacionamento. May não se contenta em ser exnamorada, e começa a prejudicar o relacionamento de Marisol e Edward, inclusive entregando a moça para a polícia (que era imigrante ilegal nos Estados Unidos). No final da novela, Edward vai à casa de May para que eles possam conversar e, quando ele entra no local, a vilã está comemorando a prisão de Marisol. Ele fica estarrecido com a situação e afirma que foi ludibriado por muito tempo. Quando May tenta se explicar, Edward segura seu braço com força e joga-a contra o sofá. A foça do golpe faz com que ela caia no chão. Assim que a vilã se levanta, ele empurra-a novamente e afirma: "Eu não quero ouvir mais nada, sabe porquê? Porque a sua voz tá me dando vontade de avançar em você". A frase final de Edward revela que as ações praticadas por ele até aquele momento não haviam sido agressões, mas tentativas de se desvencilhar da mulher que havia lhe enganado por tanto tempo.

Em Páginas da Vida (Manoel CARLOS, 2006), Marta (Lilia Cabral) é mãe de Nanda (Fernanda Vasconcellos), uma adolescente que engravida de seu namorado e acaba sendo expulsa de casa. Quando a menina deixa a residência familiar, desamparada, é criada uma cisão na família, e Alex (Marcos Caruso) - pai de Nanda e marido de Marta - passa a odiar a esposa. A primeira vez que Alex agride Marta (episódio 25, exibido em 07 de agosto) é no momento em que descobre que Nanda havia morrido em um acidente causado por uma batida entre um ônibus e um carro. Alex acusa Marta de assassinato (já que foi ela quem expulsara a filha de casa e a deixara vulnerável) e começa a esganá-la até que a mulher quase perde a respiração. Em vários outros momentos, Alex agride Marta com socos, empurrões e sufocamentos. No episódio 201 (apresentado em 26 de fevereiro de 2007), Alex está farto da postura da esposa e se direciona ao quarto dela para cobrar explicações. 
Ele entra na peça onde Marta se encontra acamada, aperta seu pescoço e afirma "Doente? Eu não acredito em nada disso, Marta. Perigosa, assassina. Eu vou te matar, Marta, eu vou te matar de verdade se você não falar", e quando a esposa tenta se desvencilhar, ele proclama: "Não adianta fugir, porque eu te encontro, te encontro em qualquer lugar. Eu te caço como um animal". E, por fim, Alex avisa: "Morrer, Marta, morrer, é isso que você merece. Você é um ser miserável que não desperta amor, não desperta piedade em ninguém, você é má".

Em Avenida Brasil (João Emanuel CARNEIRO, 2012), Carminha (Adriana Esteves) apanha de seu amante Max (Marcello Novaes) e de seu marido Tufão (Murilo Benício) em dois momentos distintos: no capítulo 156, que foi ao ar em 22 de setembro, e no 169, exibido em 08 de outubro. Ambas as agressões tinham a mesma finalidade, qual seja, ratificar quem controla a relação e é responsável por revelar e julgar as ações da vilã. Na trama, Carminha é uma antiga residente do lixão que tentou mudar de vida se casando com Genésio (Tony Ramos), que por sua vez é atropelado por Tufão e morre no início da novela. Após a morte do marido, a vilã leva sua enteada Rita (Mel Maia) para o lixão onde cresceu e abandona a garota no local. Tufão se sente culpado pela morte de Genésio, e começa a se envolver com Carminha, com quem se casa na segunda parte da narrativa. Durante seu relacionamento com Genésio e Tufão, Carminha mantém seu amante Max, que também fora criado no mesmo lixão. Juntos, eles tramam conseguir parte do dinheiro que Tufão juntou como jogador de futebol. No segundo momento da trama, Rita volta para o Brasil com o nome de Nina (Débora Falabella), e se infiltra na casa de Carminha para desmascará-la. É nesse contexto que o relacionamento de Max e Carminha começa a desmantelar e logo ele descobre que a amante tentou roubar seu dinheiro. Ele tranca Carminha no quarto, começa a esganá-la e diz: "Você está esquecendo que eu sou seu parceiro, seu parceiro não, sua vagabunda; eu fui teu capacho esse tempo todo". Ele joga-a no chão, depois a puxa pelo braço enquanto a chama de vaca, vadia e vagabunda. Novamente Carminha é jogada no chão. Max puxa-a novamente e bate no rosto da vilã, que tenta fugir. Então ele pega o cinto, tapa a boca de Carminha e começa a espancá-la.

No capítulo 169 da novela é a vez de Tufão ofender e agredir Carminha. A cena inicia com ele chamando a esposa de "desgraçada, vadia, prostituta, cadela". Ele segura a cabeça da vilã com força e pergunta se Max seria o pai da filha que supostamente tiveram juntos. Tufão puxa Carminha pelo braço para fora de sua mansão, e vai arrastando a vilã até o portão de saída, enquanto chama-a de cachorra e vagabunda. Tufão continua gritando: "Esse tempo todo me traindo aqui dentro, você vai ver o que é bom pra tosse agora". Quando ele chega na saída com a vilã, Tufão brada "vai pra rua, é aí que tu merece ficar". Jogada para fora de casa Carminha é olhada pelos vizinhos, que comentam suas armações e xingam a vilã.

Na telenovela A regra do jogo (João Emanuel CARNEIRO, 2015), presenciamos a vilã Atena (Giovana Antonelli) ser humilhada, presa em uma coleira pelo seu ex-marido Vander (Roney Vilella), e apanhar de seu amante Romero (Alexandre Nero) enquanto está amarrada. A personagem é uma estelionatária, que se envolve com homens e mulheres para roubar bens de valor e dinheiro de suas vítimas. Ela passa a ter um relacionamento com o vilão Romero, idealizador da Fundação Raiar (que era utilizada para lavagem de dinheiro) e integrante da facção criminosa da novela. Na primeira cena do capítulo 128 (26 de janeiro de 2016) vemos Atena amarrada em uma cadeira apanhando de todos que ela havia enganado ao longo da trama, dentre eles dois homens que estapeiam e cospem em seu rosto. A armadilha para prender a vilã no galpão foi preparada por Romero, seu parceiro erótico que, no fim da cena grita com a mulher, aperta sua garganta e ameaça desferir-lhe um soco. Na sequência Atena, é levada por Vander com as mãos e pés amarrados a uma cabana no meio do mato, é jogada no chão e mantida em cativeiro. Enquanto chora e implora para ser desamarrada, seu ex-marido pega uma coleira e prende no pescoço da vilã: "Você sentiu falta do teu colarzinho? ". No episódio 132 (30 de janeiro de 2016), após tentativa de fuga, Atena é perseguida pela mata e apanha novamente de Vander: dessa vez ela recebe socos e empurrões até o momento que consegue fugir.

No ano de 2017 está no ar A Lei do Amor (Maria Adelaide AMARAL, 2017). Durante o capítulo 99 (exibido em 24 de janeiro) Fausto (Tarcísio Meira) descobre que sua ex-mulher Magnólia (Vera Holtz) tinha um romance com seu genro Ciro (Thiago Lacerda). A vilã e Ciro haviam se juntado para conseguir vantagens financeiras e estratégicas no jogo político da cidade de São Dimas e também na tecelagem Costa Leitão. A farsa vem à luz durante uma exposição que teve o pretexto de comemorar os 40 anos da tecelagem. Durante o evento, num telão, são reveladas imagens de Magnólia e Ciro em momentos íntimos, escancarando o relacionamento que os dois mantiveram durante 20 anos. Nesse momento, Fausto se irrita com a situação e começa a xingar a vilã, afirmando que "essa mulher, ela não é apenas uma adúltera, uma farsante, uma vadia", mas também uma criminosa. Ele avisa para Magnólia que "todos já sabem quem você é, e vão saber o lugar que você deve estar", empurra a personagem no chão e adverte "no chão, no chão, o chão de onde você jamais deveria ter saído, criatura rastejante".

Após ser desmascarada, Magnólia vai para casa de Gigi (Mila Moreira). Enquanto elas conversam, Sebastião Bezerra (José Meyer), vulgo Tião, bate na porta, adentra na casa, diz: "Eu te 
amei, Magnólia" e logo em seguida desfere um soco na face da personagem. Gigi prontamente se enfurece com Tião, e afirma que ele poderia ser preso por bater nela. Tião retruca prontamente: "Dar um murro na cara dessa vagabunda vai me custar o que? Nem meia dúzia de cestas básicas, se tanto. O que eu devia fazer era dar um tiro no meio dessa sua cara de pau". Gigi se retira da sala para pegar gelo para o ferimento da amiga. Tião continua gritando e ameaçando a vilã: "Você foi pra cama comigo, sua vagabunda, no mesmo dia em que você foi pra cama com o Ciro" e completa "Vaca, ordinária, a minha vontade é espancar você, sua quenga ordinária, sórdida, imunda".

Nas cinco últimas cenas descritas, a agressão é perpetrada por parceiros românticos das mulheres e a violência ocorre devido ao desvio de caráter apresentado pelas vilãs, que teriam sido traiçoeiras, mentirosas e infiéis. Algumas delas (Magnólia, Carminha e Marta) inclusive se posicionavam publicamente como guardiãs de suas famílias, mas traiam maridos, ludibriavam os amantes e manipulavam os filhos e demais parentes. Os tapas, empurrões, socos e esganamentos serviam tanto como uma forma de reparar o mal que elas causaram quanto como uma "lição" para que elas aprendam a não agir de maneira tão imoral novamente.

Nas telenovelas Império (Aguinaldo SILVA, 2014) e Salve Jorge (Glória PEREZ, 2012/2013), a situação de violência sofrida pelas vilãs é muito similar: ambas são agredidas por homens pelos quais estão apaixonadas, mas que não as desejam. Elas apanham para aprender a não se intrometer na vida desses homens e para que eles possam afirmar sua posição de desprezo por mulheres com o caráter delas. Cora (Drica Moraes) de Império, é apaixonada por José Alfredo (Alexandre Nero), mais conhecido como Zé, que era o par romântico de Eliane (Malu Gali), irmã da vilã. Na primeira fase da narrativa, Cora convence Eliane a abandonar Zé que, após a decepção amorosa, foge para um local bem distante do país. Mas nessa ocasião Eliane já estava grávida de Zé, que não soube da filha que teria. Na segunda parte da trama Eliane morre e Cora fica responsável por Cristina (Leandra Leal), filha de sua irmã. Cora revela para a sobrinha que o milionário José Alfredo, agora chamado de Comendador, é seu pai. A vilã pretende atrapalhar a vida conjugal e amorosa de Zé e, ao mesmo tempo, abocanhar parte de sua fortuna. Quando Cora se torna uma ameaça real ao Comendador, ele a aborda em um beco escuro e aperta seu pescoço, avisando que é capaz de tudo se ela entrar em seu caminho (cena do episódio 31, exibido em 25 de agosto de 2014). No capítulo 71 (10 de outubro de 2014), Zé está na casa de Cora discutindo a paternidade de Cristina. Quando a vilã ameaça contar toda a história à polícia, o Comendador segura o pescoço de Cora e começa a esganá-la até que ela quase desmaie.

Lívia Marine (Cláudia Raia) de Salve Jorge, apanha de Théo (Rodrigo Lombardi), oficial da cavalaria do exército, que é apaixonado por Morena (Nanda Costa), moradora do subúrbio carioca, enganada pela facção comandada pela vilã para tráfico de pessoas com finalidade de exploração sexual. Na cena do capítulo 143 (exibido em 06 de abril de 2013) o oficial vai até a casa da vilã cobrar satisfações sobre o paradeiro de Morena. Lívia afirma que já disse tudo que sabia sobre o assunto. Quando ele ameaça ir embora, a vilã corre atrás de seu amado e pede que ele fique. Nesse momento, Théo pressiona Lívia na parede e aperta seu pescoço. Em seguida, empurra-a da sala até o quarto e joga-a na cama, ameaça-a e vai embora.

Nas cenas relatadas acima é possível testemunhar a trajetória típica das vilãs de telenovelas brasileiras: elas iniciam a trama em uma posição de dominância e, posteriormente, são desmascaradas e precisam lidar com as consequências de sua ambição e se responsabilizar por suas condutas. Apesar das diferenças contextuais que marcam a trajetória dessas personagens, todas elas têm em comum o fato de estarem constantemente expostas à violência, principalmente aquela perpetrada por homens com os quais convivem.

No Quadro 1, apresentado abaixo, são evidenciados os quatro principais elementos que compõem as cenas: a) a personalidade das vilãs nas narrativas; b) a finalidade da violência que elas sofreram; c) os tipos de agressões físicas e morais perpetradas e; d) o papel dos homens agressores. É possível notar uma similaridade de características em cada um desses componentes, nas diversas tramas analisadas: todas as mulheres possuíam na história um "desvio de caráter" (eram ambiciosas, promíscuas, mentirosas, gananciosas, manipuladoras), apresentado como o estopim das situações de violência, que possuíam finalidades específicas (disciplinamento, desprezo, vingança). As agressões também são correlatas, com destaque para empurrões, esganamentos, xingamentos e humilhações diversas. Todos os homens possuíam algum grau de intimidade com as vilãs, convivendo com elas em espaços familiares e íntimos.

A violência, que se manifesta principalmente na forma de agressão física e verbal e também por meio da humilhação (pública ou privada), aparece na trama como o momento de castigar e educar as mulheres. Essa sequência ritualística presente nas cenas analisadas - que consiste em fustigar e em seguida expor a pessoa molestada - possui uma função pedagógica, que tem por objetivo evidenciar os erros cometidos e proporcionar o arrependimento pelas ações realizadas. Nesse sentido, a violência está inserida em um contexto de punição merecida e necessária, afinal essas mulheres estariam recebendo um tratamento proporcional às maldades que fizeram. 
Quadro 1 - Elementos das cenas de violência sofrida por vilãs de telenovelas brasileiras

\begin{tabular}{|c|c|c|c|c|}
\hline Valss & $\begin{array}{l}\text { Personalidade das } \\
\text { vilss ua sarrativa }\end{array}$ & $\begin{array}{l}\text { A finslidade da } \\
\text { violiacia }\end{array}$ & $\begin{array}{l}\text { Topos de agressio } \\
\text { sofridas }\end{array}$ & $\begin{array}{l}\text { Papel do bomem } \\
\text { agressed ua } \\
\text { narrativa }\end{array}$ \\
\hline Ĺts & $\begin{array}{l}\text { Oferecida, exbida (se } \\
\text { insima para virios } \\
\text { homens) e mentrosa. }\end{array}$ & $\begin{array}{l}\text { Deckplimamento e } \\
\text { educasio }\end{array}$ & $\begin{array}{l}\text { Empurrdes, barho } \\
\text { forçado e tapas } \\
\text { xingamentos fversos } \\
\text { e humilhaça }\end{array}$ & $\begin{array}{l}\text { Pecto é par } \\
\text { romintico e } \\
\text { desempentha } \\
\text { tambeim ums fincia } \\
\text { paterna (por meio da } \\
\text { woltacia) }\end{array}$ \\
\hline Déris & $\begin{array}{l}\text { Ingata, ambiciosa e } \\
\text { peomiscua }\end{array}$ & $\begin{array}{l}\text { Disciplinamento e } \\
\text { edtocaybo }\end{array}$ & $\begin{array}{l}\text { Agressio cotal cinbo, } \\
\text { empurdes, } \\
\text { esganamentos e } \\
\text { exposiçio pubica }\end{array}$ & $\begin{array}{l}\text { Carlao desemperha } \\
\text { sua frucilo patema } \\
\text { (bom pai) }\end{array}$ \\
\hline May & Severa e obsessiva & $\begin{array}{l}\text { Despreso e } \\
\text { indfereaca }\end{array}$ & Empurdes & $\begin{array}{l}\text { Edward é ex- } \\
\text { aamorado }\end{array}$ \\
\hline Marta & Rancorosa e impiedosa & $\begin{array}{l}\text { Vingança e byso } \\
\text { moral }\end{array}$ & $\begin{array}{l}\text { Empurōes, } \\
\text { espansmentos, socos, } \\
\text { xhagamentos e } \\
\text { ameaças }\end{array}$ & Alex è marido \\
\hline Carminha & $\begin{array}{l}\text { Gananciosa, promiscus, } \\
\text { obstinada e } \\
\text { maniculadora. }\end{array}$ & $\begin{array}{l}\text { Vingança, desprezo } \\
\text { e kplo moral }\end{array}$ & $\begin{array}{l}\text { Surra de cinto, tapas } \\
\text { ao rosto, empursues, } \\
\text { xingamentos, ofensas } \\
\text { e humilhaçà puibica. }\end{array}$ & $\begin{array}{l}\text { Max é amante e } \\
\text { Tuffos, maxido }\end{array}$ \\
\hline Atena & $\begin{array}{l}\text { Ganinaciosa, protutecuz, } \\
\text { criminosa e } \\
\text { inescrupulosa }\end{array}$ & $\begin{array}{l}\text { Despeeso e } \\
\text { vinganga }\end{array}$ & $\begin{array}{l}\text { Ameacak, prisiso em } \\
\text { cativero, uso de } \\
\text { coleka e humilhaçio }\end{array}$ & $\begin{array}{l}\text { Vander te ex-marido } \\
\text { e Romero é amante }\end{array}$ \\
\hline Maznolia & $\begin{array}{l}\text { Oberinada, mertirosa, } \\
\text { gananciosa e } \\
\text { manipuladora }\end{array}$ & $\begin{array}{l}\text { Despeeso e } \\
\text { vinganga }\end{array}$ & $\begin{array}{l}\text { Empurrōes, socos, } \\
\text { xingamentos e } \\
\text { lumuilhagso püblica }\end{array}$ & $\begin{array}{l}\text { Fausto tex-marido } \\
\text { e Tìo amanke }\end{array}$ \\
\hline Cora & $\begin{array}{l}\text { Mertirosa, } \\
\text { manivuladora e } \\
\text { ganianciosa }\end{array}$ & $\begin{array}{l}\text { Desperso e } \\
\text { intimidaça }\end{array}$ & Espanamentos & $\begin{array}{l}\text { Cora te apabuceada } \\
\text { por José Afredo }\end{array}$ \\
\hline Lwa & $\begin{array}{l}\text { Criminosa e } \\
\text { mankpuladora }\end{array}$ & $\begin{array}{l}\text { Despreso e } \\
\text { intimidaçio }\end{array}$ & $\begin{array}{l}\text { Espanamentos e } \\
\text { empurvos: }\end{array}$ & $\begin{array}{l}\text { Linis é apaixonada } \\
\text { por Théo }\end{array}$ \\
\hline
\end{tabular}

Fonte: autoria própria.

A violência desponta em um momento da narrativa no qual as atitudes nefastas e escusas das vilãs já são conhecidas e comprovadas, e as agressões passam a ter uma motivação de fácil apreensão, adentrando em um contexto de causalidade que as torna, inclusive, necessárias. Os tapas, socos, chutes, ameaças, xingamentos e esganamentos aparecem nas cenas, no ápice da prática das maldades, e se constituem como divisores de águas na trama, na medida em que essas mulheres mudam suas atitudes após a lição que receberam (aquelas que não se arrependem e se retratam estão sujeitas a finais trágicos, como Marta que enlouqueceu ao final de Páginas da vida).

A trajetória das vilãs nas narrativas está inserida em uma moralidade representada pela telenovela, que centraliza a oposição entre a boa versus a má mulher: a heroína, que se apaixona verdadeiramente, é honesta e leal em oposição à vilã, que se aproxima dos outros personagens por interesses escusos, é mentirosa, criminosa e falsária. O caráter corrompido aparece também como justificativa para as agressões, já que as mulheres violentadas romperam com as expectativas 
atribuídas ao papel que deveriam desempenhar - elas extrapolaram os "bons" valores e condutas, e se emaranharam pelo caminho da maldade e promiscuidade. Outro fator que corrobora esta observação é a raridade em que é possível presenciar vilões em situações de degradação física e moral intensa como as relatas neste texto. Inclusive, nas novelas analisadas, dois agressores eram vilões e nem sequer apareceram sendo espancados e humilhados quando descobertas suas farsas e tramoias. Em Avenida Brasil, quando Carminha é descoberta, Max também é desmascarado. Enquanto a vilã apanha do marido e de seus familiares, Max apenas foge de casa e seu final é ser assassinado. Carminha é humilhada no bairro do Divino, volta a viver no lixão e se arrepende de tudo que fez para Nina e Tufão. Romero de $A$ regra do Jogo sofre algumas agressões ao longo da novela, principalmente pelas mãos da facção da qual faz parte, mas em nenhum momento é violentado e humilhado como Atena.

A violência sofrida pelas vilãs, constituída da forma exposta acima, é marcadamente uma violência de gênero, que ocorre em âmbitos relacionais e interpessoais e é concentrada, sobretudo, nos corpos das mulheres (Lourdes BANDEIRA, 2014) apresentadas nas tramas, em contexto de assimetria de poder. Ademais, os atributos e papéis de gênero adentram nas narrativas para configurar um quadro moral no qual se inserem essas mulheres (boas versus más), e passam a justificar as agressões, que aparecem como corretivas. É a atribuição de valor moral diferencial, a partir daquilo que se considera ser uma atuação adequada do gênero feminino que situa determinadas mulheres como sujeitas a agressões e humilhações.

A violência do homem contra a mulher, como afirma Heleieth Saffioti (1994, 2001), é uma "modalidade material de controle social", constitutiva da organização de gênero no Brasil, uma vez que é generalizada e tolerada em instâncias formais e socioculturais. Essa violência é um fenômeno multifacetado que abriga diversas modalidades de abusos físicos (tapas, socos, espancamentos), sexuais (estupro, reprodução forçada) e psicológicos (chantagem, ironia, xingamentos), e é marcada principalmente por uma moralidade que define a divisão binária e hierárquica dos gêneros no corpo social - definindo papéis e condutas distintos para homens e mulheres.

Maria Filomena Gregori (1989) adensa essa discussão ao demonstrar como o rompimento com as divisões de papéis atribuídos a homens e mulheres desencadeia um desequilíbrio de forças que colabora para o desenvolvimento de relações violentas; o reestabelecimento da estabilidade passaria necessariamente pela readequação às condutas normatizadas. Existe, portanto, uma correlação entre o investimento em determinadas posições de gênero e a violência interpessoal: "Nesse sentido, a violência, quando ocorre, é resultado de uma crise de representação, e também um resultado do conflito entre estratégias sociais que estão intimamente ligadas a esses modos de representação" (Henrietta MOORE, 2000, p. 41).

Nas cenas das telenovelas, despontam os mecanismos comentados tanto por Saffioti como por Gregori e Moore, conformando a violência em tela: em primeiro lugar, a conduta das vilãs destoa do padrão estabelecido pela novela como digno e aceitável (que está atrelado às heroínas); os papéis atribuídos às mulheres (que na maioria dos casos possuem relação com o lar e a família) são rompidos pelas personagens malfeitoras, que apresentam um desvio de caráter (na medida em que elas não são dóceis, amáveis, femininas e respeitáveis, mas vagabundas, safadas, quengas, etc.); nesse contexto, elas enganam vários homens (aqueles que posteriormente irão agredi-las) e subvertem a posição que eles deveriam ocupar (de dominância e controle, já que eles geralmente estão à frente dos negócios e das decisões da família); a violência ocorre em um momento de transformação da trama, no qual o equilíbrio das forças é reestabelecido (as vilãs apanham para reassumirem uma posição adequada como mulher).

O caminho habitual das agressões contra as vilãs, exposto acima, não é questionado nas tramas, mas naturalizado - ele é o desdobramento narrativo esperado dentro da teledramaturgia. A diferença de poder estabelecida social e narrativamente permite que os personagens masculinos assumam uma função pedagógica e corretiva, mesmo que seja através de atos violentos; ao mesmo tempo, consente que as mulheres devam se comportar de determinadas formas ou, ao contrário, possam estar sujeitas à violência. A naturalização das dissimetrias de poder seleciona aquelas que podem (ou até mesmo precisam) ser violentadas e humilhadas - compondo um quadro que dificulta a apreensão da violência, na medida em que, como afirmam Gregori e Guita Grin Debert (2008), o reconhecimento das desigualdades de poder são essenciais para edificar uma avaliação de diversos atos como abusivos.

É interessante frisar, a fim de adensar ainda mais o argumento desenvolvido até o momento, que várias telenovelas brasileiras buscaram inserir o tema da violência contra a mulher em suas tramas, como por exemplo em Mulheres Apaixonas de 2003 (uma das personagens apanha de raquete do marido), Fina Estampa de 2011 (a mulher apanha do marido alcoólatra), A Regra do Jogo de 2015 (mulher apanha do marido que a trai e rouba seu dinheiro), dentre outras. Entretanto, diferentemente das cenas relatadas, as mulheres violentadas eram pessoas honestas, em relacionamentos estáveis e com um comportamento exemplar, não apresentando nenhum traço ou característica que justifique a violência que elas sofriam. É aí que reside o problema das cenas analisadas neste texto: a violência é justificada mediante o contexto, o que implica em relativizar 
quais tipos de agressão serão consideradas violência de gênero e quais serão compreendidas como corretivos necessários.

No conjunto de elementos destacados é possível assinalar dois processos principais por meio dos quais a violência de gênero é abrandada na trajetória das vilãs: a) as agressões aparecem como algo necessário para corrigir determinada conduta que não se enquadra dentro da moralidade constituída e b) as normatividades que condicionam a aparição do gênero são acionadas durante as cenas de espancamento (principalmente quando os homens tacham as mulheres de vadias, putas, vacas, etc.), qualificando a imoralidade dessas mulheres e justificando a ação dos homens. Diante desse quadro, é preciso enfrentar a questão do significado da difusão desse regime de representação na arena pública, na qual a televisão se insere, e as possíveis consequências da justificação da violência contra a mulher em contextos específicos (nos quais elas extrapolaram aquilo que é considerado possível e adequado).

\section{O espaço moral midiático e as cenas de violência contra a mulher}

Contemporaneamente, conforme revela Roger Silverstone (2007), os dispositivos midiáticos têm assumido, cada vez mais, o papel de mediadores da realidade social, edificando representações do mundo e circunscrevendo a relação estabelecida com outros próximos e distantes. Destarte, os meios de comunicação fornecem enquadramentos determinados que circunscrevem a apreensão dos outros (principalmente aqueles que são visíveis apenas por meio dos media), incidindo diretamente na relação que é possível estabelecer com eles e possibilitando ou impedindo o reconhecimento da alteridade. Essa discussão é fundamental para situar as imagens de violência de gênero debatidas por este texto, principalmente porque elas não aparecem somente como uma agressão, mas como um momento de correção e aprendizado para determinadas mulheres. A relativização da violência de gênero a partir de contextos e práticas específicas colaboram para posicionar determinadas mulheres em situação de extrema precariedade, situando-as aquém de qualquer tipo de resposta ética.

Nas telenovelas analisadas a relação estabelecida entre a tipicidade dos personagens e aquilo que é emblemático que lhes ocorra é o primeiro elemento que aponta para o problema moral de determinadas formas de representação ficcional. As trajetórias das personagens estão submersas em um caminho linear e culminam em finais já conhecidos, tornando as narrativas previsíveis e fazendo com que os desfechos sempre revelem os destinos previstos de heróis e vilões. Dessa forma, as representações de diversos sujeitos são instituídas em um enquadramento tipicamente estabelecido.

É exatamente essa construção narrativa que abranda o sentido da violência perpetrada contra vilãs, personagens que estão fadadas a agressões para iniciar um processo de reconhecer e aprender com os erros. Elas só puderam apanhar sem gerar uma onda de questionamentos e inquietações porque tiveram o destino que mereciam dentro da trama, e estariam apenas pagando por ter transgredido fronteiras morais e de gênero'. Além do já exposto, o marco normativo que constitui as telenovelas do bem versus o mal passa a definir diferencialmente a posição dos sujeitos representados.

É preciso, então, compreender como a telenovela (e também as diversas representações factuais e ficcionais) dimensiona o tipo de relação estabelecida com o outro representado, principalmente aqueles que estão enquadrados como aquém do quadro moral posto em tela. Essa configuração midiática expõe determinados personagens a uma série de danos (físicos e psicológicos), sem que seja possível questionar a violência que sofrem (ou ainda pior, sem que essa violência seja ao menos reconhecida).

Essa questão está diretamente relacionada aos marcos de reconhecimento específicos que concorrem para constituir regimes de representação de determinados sujeitos no espaço midiático. Conforme a perspectiva de Judith Butler (2010), a edificação de enquadramentos diferenciais para a apreensão daqueles que sofrem violência faz com que alguns sejam visíveis no espaço público mediado por tecnologias de comunicação enquanto outros são totalmente invisibilizados. Os media colaboram, segundo a autora, na estruturação e na percepção de tais marcos de reconhecimento, na medida em que mobilizam avaliações e julgamentos sobre os outros. Nesse sentido, podem, inclusive, restringir a inteligibilidade de determinados indivíduos, já que condicionam o que pode ser visto, ouvido e reconhecido.

Aqueles que extrapolam os marcos de reconhecimento estão sujeitos à violência (Judith BUTLER, 2004), e também são passíveis de serem enquadrados como pessoas para quem ela é natural ou, inclusive, necessária. As concepções normativas de gênero estão diretamente relacionadas à esfera do reconhecimento, na medida em que desenvolvem condutas apropriadas

\footnotetext{
${ }^{6}$ Ao acompanhar os resumos dos capítulos analisados em diferentes veículos de mídia online foi possível perceber como essas cenas de violência são esperadas pelo público e aclamadas pelos colunistas de novelas (são inclusive episódios com altos índices de audiência). Sempre com títulos bombásticos, as matérias apontam as possíveis agressões que as vilãs sofrerão e fornecem uma explicação das possíveis transformações da personagem após a violência.
} 
e inapropriadas, que são a base para a banalização das agressões sofridas pelas vilãs. A violência de gênero é compreendida de modo diferencial porque as próprias normatividades que a regem são gestadas em marcos específicos de reconhecimento, que fundamentam quais sujeitos podem ou não sofrer abusos. Os xingamentos proferidos no momento das agressões evidenciam plenamente a discussão empreendida até aqui, demonstrando quais são as mulheres que podem ser violentadas: as cadelas, as putas, as vadias, as pistoleiras, as piranhas, as interesseiras, as biscates, as vilãs.

\section{Considerações finais}

Ao longo do presente texto foram analisadas cenas de violência perpetradas por maridos, amantes e pais contra vilãs de nove telenovelas brasileiras. Foram percorridos 17 anos dessas narrativas ficcionais, evidenciado a ampla ocorrência de cenas de agressão contra mulheres, cenas estas gestadas em um regime de representação que abranda sua gravidade. Todas as imagens estão inseridas em um contexto social e político no qual a violência contra a mulher apresenta números chocantes e é constitutiva das relações de gênero.

Os meios de comunicação, ao exibirem tais cenas a partir de um regime de representação que justifica a violência contida nelas, colaboram para reforçar os marcos de reconhecimento diferenciais que circunscrevem as mulheres que podem e devem apanhar, situando-as aquém de uma resposta moral de responsabilidade e cuidado. Para as vilãs (e para as mulheres que transgridem as normatividades de gênero, extravasando as possibilidades de inteligibilidade) só resta rejeição e agressão (ou, no melhor dos casos, se enquadrarem de bom grado nos padrões de conduta e valores considerados adequados ao gênero feminino).

\section{Referências}

BANDEIRA, Lourdes. "Violência de gênero: a construção de um campo teórico e de investigação". Sociedade e Estado, Brasília, v. 29, n. 2, p. 449-469, maio/ago. 2014.

BUTLER, Judith. Undoing gender. New York: Routledge, 2004.

BUTLER, Judith. Marcos de guerra: Ias vidas lloradas. Buenos Aires: Paidós, 2010.

GREGORI, Maria Filomena. "Cenas e queixas: mulheres e relações violentas". Novos Estudos CEBRAP, São Paulo, n. 23, p. 163-175, março 1989.

GREGORI, Maria Filomena; DEBERT, Guita Grin. "Violência e gênero: novas propostas, velhos dilemas". Revista Brasileira de Ciências Sociais, São Paulo, v. 23, n. 66, p. 165-185, fev. 2008.

IBGE. Síntese dos indicadores sociais (SIS). Rio de Janeiro, 2010. Disponível em: http:// biblioteca.ibge.gov.br/pt/biblioteca-catalogo?view=detalhes\&id=245700. Acesso em: 20 ago. 2017.

INSTITUTO PATRÍCIA GALVÃO. Dossiê Violência contra as mulheres. São Paulo, 2013. Disponível em: http://www.agenciapatriciagalvao.org.br/dossie/sobre-as-violencias-contra-a-mulher/. Acesso em: 20 ago. 2017.

LOIZOS, Peter. "Vídeo, filme e fotografias como documentos de pesquisa". In BAUER, M \& GARSKELL, G. Pesquisa qualitativa com imagem, texto e som. Petrópolis: Vozes, 2002. p. 137-155.

MOORE, Henrietta. "Fantasia de poder e fantasia de identidade: gênero, raça e violência". Cadernos Pagu, Campinas, n. 14, p. 13-44, jan. /jun., 2000.

ROSE, Diana. "Análise de imagem em movimento". In. BAUER, M \& GARSKELL, G. Pesquisa qualitativa com imagem, texto e som. Petrópolis: Vozes, 2002. p. 343-364.

SAFFIOTI, Heleieth. "A violência de gênero no Brasil atual". Revista Estudos Feministas, Florianópolis, v. 2, número especial, p. 443-461, agosto/dezembro1994.

SAFFIOTI, Heleieth. "Contribuições feministas para o estudo da violência de gênero". Cadernos Pagu, Campinas, n. 16, p. 115-136, ago/dez, 2001.

SILVERSTONE, Roger. Media and morality: on the rise of mediapolis. Cambridge: Polity Press, 2007.

Referências das telenovelas

CARLOS, Manuel. Laços de Família. (telenovela). GÓES, Moacyr; NERY, Leandro (Dir.). Brasil: Rede Globo de Televisão, 2000. 
CARLOS, Manoel. Mulheres Apaixonadas (telenovela). TRAVESSO, Marcelo; COSLOV, Ary (Dir.) Brasil; Rede Globo de Televisão, 2003.

CARLOS, Manoel. Páginas da Vida (telenovela). MONJARDIM, Jayme; MANBERTI,

Fabrício; LAMPREIA, Teresa; MAYRINK, Frederico; SABINO, Luciano (Dir.) Brasil: Rede Globo de Televisão, 2006.

CARNEIRO, João Emanuel. Avenida Brasil (telenovela). FERNANDEZ, Gustavo; TEITELROIT, Thiago; SILVESTRINI, Paulo; CÂMARA, André; JABACE, Joana (Dir.) Brasil: Rede Globo de Televisão, 2012.

CARNEIRO, João Emanuel. A regra do jogo (telenovela). TRAVESSO, Marcelo; SAUER, Henrique; DIAZ, Enrique; BOTELHO, Guto Arruda (Dir.) Brasil: Rede Globo de Televisão, 2015.

PEREZ, Glória. América (telenovela). MONJARDIM, Jayme; SCHECHTMAN, Marcos; SABINO, Luciano; TRAVESSO, Marcelo; LAMPREIA, Teresa; BONANI, Federico; MILANI, Carlo (Dir.) Brasil, Rede Globo de Televisão, 2005.

PEREZ, Glória. Salve Jorge (telenovela). SABINO, Luciano; KLEMPERER, Alexandre; MELO, Adriano; BOLTSHAUSER, João; JABUR, João Paulo (Dir.) Brasil: Rede Globo de Televisão, 2012/2013.

SILVA, Aguinaldo. Império. (telenovela). BOECKEL, Cláudio; OLIVEIRA, Luciana; RICHARD, Roberta, BRESSANE, Tande; LACERDA, Davi (Dir.) Brasil: Rede Globo de Televisão, 2014.

Lorena Rúbia Pereira Caminhas (iD) 0000-0003-1009-3880

Doutoranda em Ciências Sociais pela Universidade Estadual de Campinas

Mestra em Comunicação Social pela Universidade Federal de Minas Gerais (UFMG). Membra do Grupo de Estudos Interdisciplinares em Ciência e Tecnologia (GEICT/UNICAMP), certificado pelo CNPq. Possui experiência em pesquisas na área de Gênero e Sexualidade, sobretudo no que tange aos mercados do sexo, e no campo da Comunicação, especialmente em moralidades midiáticas e mídia e gênero.

Universidade Estadual de Campinas, Instituto de Filosofia e Ciências Humanas, Departamento de Ciências Sociais

Rua Cora Coralina, 100, Cidade Universitária Zeferino Vaz, Barão Geraldo.

13083-896 - Campinas - SP - Brasil

(19) 3521-0121 - scpgcsoc@g.unicamp.br

lorenarubiapereira@gmail.com

COMO CITAR ESSE ARTIGO DE ACORDO COM AS NORMAS DA REVISTA

CAMINHAS, Lorena Rúbia Pereira. "Imagens de violência de gênero em telenovelas brasileiras" Revista Estudos Feministas, Florianópolis, v. 27, n. 1, e52253, 2019.

CONTRIBUIÇÃO DE AUTORIA

Não se aplica

FINANCIAMENTO

Não se aplica

CONSENTIMENTO DE USO DE IMAGEM

Não se aplica

APROVAÇÃO DE COMITÊ DE ÉTICA EM PESQUISA

Não se aplica

CONFLITO DE INTERESSES

Não se aplica 


\section{LICENÇA DE USO}

Este artigo está licenciado sob a Licença Creative Commons CC-BY. Com essa licença você pode compartilhar, adaptar, criar para qualquer fim, desde que atribua a autoria da obra.

\section{HISTÓRICO}

Recebido em 18/08/2017

Reapresentado em 06/11/2017

Aprovado em 21/05/201 8 